\title{
Drying Characteristics of Osmotically Pretreated Red Onion Slices via Hot Air Oven
}

\author{
Hussein $\mathrm{JB}^{1}$, Soji $\mathrm{MY}^{1}$, Abiona $\mathrm{OO}^{2}$ and Oke $\mathrm{MO}^{3^{*}}$ \\ ${ }^{1}$ Department of Food Science and Technology, Modibbo Adama University of Technology, Yola, Adamawa State, Nigeria \\ ${ }^{2}$ Department of Chemical Sciences, Osun State University, Osogbo, Osun State, Nigeria \\ ${ }^{3}$ Department of Food Science and Engineering, Ladoke Akintola University of Technology, Ogbomoso, Oyo State, Nigeria
}

\begin{abstract}
The drying characteristics of osmotically pretreated red onion slices via hot air oven at different drying temperatures $\left(40^{\circ} \mathrm{C}\right.$ to $\left.80^{\circ} \mathrm{C}\right)$ and $1.5 \mathrm{~m} / \mathrm{s}$ air velocity was investigated. Fresh onion bulb was manually sliced $(4 \pm 0.2 \mathrm{~mm})$ and pretreated in $20 \%$ osmotic solution (sucrose, salt and water in ratio 1:1:4 weight in grams) for 2 hours. Eight drying models (Page, Logarithmic, Henderson and Pabis, Newton (Lewis), Wang and Singh, Parabolic, Midilli and Prakrash and Kumar) were used to optimize the goodness of fit to the experimental data. The models were compared using coefficient of determination $\left(R^{2}\right)$, chi-square $\left(X^{2}\right)$ and root mean square error (RMSE). Some selected functional properties of the dried onion were also examined. It took $660 \mathrm{~min}, 600 \mathrm{~min}, 390$ min, $300 \mathrm{~min}$ and $180 \mathrm{~min}$ at $40^{\circ} \mathrm{C}, 50^{\circ} \mathrm{C}, 60^{\circ} \mathrm{C}, 70^{\circ} \mathrm{C}$ and $80^{\circ} \mathrm{C}$ respectively to dry dehydrated red onion from $82.14 \%$ (wet basis) moisture content to constant equilibrium moisture content. The drying took place only in a falling rate period. The Midilli model was found to best fit the experimental data compared to other models. The effective moisture diffusivity values were found to be $1.76838 \times 10^{-10} \mathrm{~m}^{2} / \mathrm{s}$ for $40^{\circ} \mathrm{C} ; 1.98 \times 10^{-10} \mathrm{~m}^{2} / \mathrm{s}$ for $50^{\circ} \mathrm{C} ; 3.11 \times 10^{-10} \mathrm{~m}^{2} / \mathrm{s}$ for $60^{\circ} \mathrm{C} ; 4.26 \times 10^{-10} \mathrm{~m}^{2} / \mathrm{s}$ for $70^{\circ} \mathrm{C}$ and $7.03 \times 10^{-10} \mathrm{~m}^{2} / \mathrm{s}$ for $80^{\circ} \mathrm{C}$ respectively. The activation energy $\left(E_{a}\right)$ was found to be $29.67 \mathrm{KJ} / \mathrm{mol}$. The results of these measures have confirmed the consistency of the developed model to describe satisfactorily the drying characteristics of red onion slices at different drying temperature.
\end{abstract}

Keywords: Red onion; Osmotic pretreatment; Drying characteristics; Hot air oven

\section{Introduction}

Onion (Allium cepa L.) is a famous vegetable commodity grown all over the world and consumed in the various forms. According to the United Nations Food and Agricultural Organizations, the world total onion production is 8.90 million tonnes. India was the leading country with an estimated production of 5.51 tonnes follows by Nigeria with an estimation of 1.98 million tonnes [1]. Onion is an indispensable item in every kitchen as condiment and vegetable. It is has been widely used as seasonings, foods (either in raw form or dehydrated form to add favour and taste) and for medical uses since the ancient times [2]. With more emphasis on disease prevention than cure, there has been an increased interest by scientists on the high content of polyphenolic flavonoids in onions [3]. Onion and leek are high in flavonoids [4]. Even though the onion has high nutritional value, it is largely consumed for its unique flavour and its ability to improve the flavour of other foods [5]. Sixtytwo percent of the world's production is from Asiatic countries. India is the world's second largest producer of onion [6] while it was the third most popular in South Africa, after potatoes being first and tomatoes being second. In Nigeria, onion is the second most important vegetable after tomato. Its main production is from the Northern part of the country where considerable quantity is produced annually [7].

Onion has special qualities, which add to taste and flavour to food and hence it is mainly used in India for cuisine and culinary preparations. Besides adding a delicious taste and flavour, onion serves as an appetizer, food digester and health promoter. It also serves as a good medicinal compound for cataract, cardiovascular disease and cancer due to its hypocholesterolemic, thrombolitic and antioxidant effects as reported by Block [8]. Onions are highly perishables, since they are extremely sensitive to heat and humidity thus, they require much care from harvest to transport, with special attention for packing and storage. Onions are available in large quantity during the harvesting season of which Most of them are not utilized properly due to oversupply in peak season, lack of adequate processing technology, preservation, adequate transportation and marketing facilities. The losses include decay or rotting, sprouting, physiological loss of weight, splitting of bulbs, discoloration, shrinkage, descaling and rooting. Dehydration processes offer an alternative way of using onion for consumption and the dehydration of onions like other vegetables have been practiced for many years as a means of preservation [9]. Dried onion products are produced in several forms such as; faked, minced, chopped and powdered [2]. Kaymak-Ertekin and Gedik [10] reported that dehydrated onion has become a standard food ingredient in a wide range of food products such as ketchup, soups, salad dressings, sausage and meat products, potato chips, crackers, and many other convenience foods.

In spite of these, Onion is mainly known for its characteristic flavour which adds a delicious taste to almost all the food preparations. Since ancient times, onion has been mainly used for its cuisine and culinary properties. Therefore, the main challenge has been to preserve the pungent taste, flavour, and colour of onion along with the desired moisture content as it is responsible for most of the deteriorative microbial reactions, for safe storage life and rehydration ratio during dehydration process [11]. Hot air dehydration has been largely employed to preserve fruits and vegetables. In order to obtain high quality dehydrated food, there is a need to modify this drying method so as to limit its adverse influence, especially on flavour, colour, nutrients and fruit tissue. One possible solution is to apply osmotic dehydration,

*Corresponding author: Oke MO, Department of Food Science and Engineering Ladoke Akintola University of Technology, Ogbomoso-4000, Oyo State, Nigeria, Tel: +234-8067624977; E-mail: mooke47@lautech.edu.ng

Received April 17, 2018; Accepted May 08, 2018; Published May 15, 2018

Citation: Hussein JB, Soji MY, Abiona OO, Oke MO (2018) Drying Characteristics of Osmotically Pretreated Red Onion Slices via Hot Air Oven. J Food Process Technol 9: 733. doi: 10.4172/2157-7110.1000733

Copyright: @ 2018 Hussein JB, et al. This is an open-access article distributed under the terms of the Creative Commons Attribution License, which permits unrestricted use, distribution, and reproduction in any medium, provided the original author and source are credited. 
which involves the immersion of fruit in osmotic solution resulting in the removal of water from tissue, and replacing it with soluble solids as a pretreatment $[12,13]$.

Osmotic dehydration is the most reported pretreatment used prior to air-drying $[14,15]$. It removes water from the fruit or vegetable up to a certain level, which is still high for food preservation so that this process must be followed by another process in order to lower even more the fruit water content [16]. It is a useful technique that involves the immersion of the fruit in a hypertonic aqueous solution leading to the loss of water through the cell wall membranes of the fruit and subsequent flow along the inter-cellular space before diffusing into the solution [17]. As a partial dehydration process, osmosis may be regarded as a simultaneous water and solute diffusion operation, wherein the sample incurs a gain of solids and a simultaneous loss of moisture [18]. The shelf life quality of the final product is better than without such treatment due to the increase in sugar/acid ratio, the improvement in texture and the stability of the colour pigment during storage [14]. Osmotic dehydration preceding air drying decreases colour changes and increases flavour retention in dried fruits and vegetables [15]. The resulting product has generally better quality than the dried one without pretreatment. Ade-Omowaye et al. [19] also reported that osmotic pretreatment reduced heat damage, improved textural quality, vitamin retention, flavour enhancement and colour stabilization.

In order to successfully transfer knowledge acquired experimentally from studies on food dehydration into industrial applications, mathematical modelling of drying kinetics is required. Moreover, a mathematical model is an important tool used to optimize operating parameters and to predict performance of a drying system [20]. Numerous mathematical models, empirical and semi-empirical, have been proposed to estimate the drying characteristics of agricultural products [21]. These simple models, also known as thin layer models, allow prediction of mass transfer during dehydration and are applied to simulate drying curves under similar conditions [22,23]. Many researches have been conducted on the mathematical modeling and experimental studies on thin layer drying processes of various vegetables and fruits, such as green bean [24,25] red pepper [26], mint leaves [27], tarragon [28], potato[29], chilli pepper [30], carrot [31], citrus aurantium leaves [32], tomato slice [33-35] and Onion slice [16]. However, few reports have focused on the evaluation of a suitable drying model for describing the drying kinetic of osmotically pretreated red onion varieties. Therefore, the aim of this study was to investigate the influence of pretreatments and drying air temperature on the drying kinetic of osmotically pretreated red onion varieties.

\section{Materials and Methods}

\section{Raw material preparation}

The fresh Onion bulbs (Allium cepa) (red species) used for this study were purchased from Jimeta modern market Yola, Adamawa State, Nigeria. The onion bulbs was stored in a storage chamber at a temperature of $4^{\circ} \mathrm{C}$ $\pm 1^{\circ} \mathrm{C}$ and $70 \%$ air relative humidity to allow it equilibrate with ambient temperature. The fresh red onion bulbs were thoroughly washed with tap water to remove adhering debris, hand peeled and cut into circular slices (direction perpendicular to the vertical axis) of thickness equal to $4 \pm 0.5 \mathrm{~mm}$ using a manual stainless knife. Initial moisture content of the sample was determined using the oven drying method according to the AOAC [36] method (number 934.01) and found to be $82.14 \pm 0.28$ $\mathrm{g}$ water per $100 \mathrm{~g}$ sample.

\section{Osmotic dehydration of onion}

Osmotic solution of $20 \%$ Brix concentration was prepared using the equation 1 as described by Ade-Omowaye et al. [19]. One (1) Kg of onion was immersed in a beaker containing the osmotic solution (sucrose, salt and water in ratio 1:1:4 weight in grams) for 2 hours. This solution was stirred at interval of fifteen minute (15 min).

$$
\frac{x}{x+y}=z \%
$$

Where,

\section{$\mathrm{X}$ : Weight of sugar and salt,}

Y: Weight of solvent i.e., distilled water,

$\mathrm{Z}$ : Percentage of the weight/weight of ${ }^{\circ}$ Brix.

\section{Drying procedure}

Hot air oven (Model: TO008GA-34, AKAI-Tokoyo, Japan) was used for the drying. The osmotically pre-treated onion slices were divided into five equal portions. The first portion was dried at $40^{\circ} \mathrm{C}$ air temperature and a constant $1.5 \mathrm{~m} / \mathrm{s}$ airflow velocity. The moisture loss was recorded in $5 \mathrm{~min}$ interval for an hour, then the weighing interval was increased to $10 \mathrm{~min}$ for next one hour the further readings was taken at $15 \mathrm{~min}$ interval by a digital balance of $0.01 \mathrm{~g}$ accuracy. The drying was continue till constant weight is reached and the drying was replicated three times. The drying procedure was repeated for the air-drying temperature of $50^{\circ} \mathrm{C}, 60^{\circ} \mathrm{C}, 70^{\circ} \mathrm{C}$ and $80^{\circ} \mathrm{C}$ and $1.5 \mathrm{~m} / \mathrm{s}$ constant airflow velocity.

\section{Mathematical modelling}

Determination of moisture ratio: The moisture ratio of onions slices dried at $40^{\circ} \mathrm{C}, 50^{\circ} \mathrm{C}, 60^{\circ} \mathrm{C}, 70^{\circ} \mathrm{C}$ and $80^{\circ} \mathrm{C}$ air temperature at a given time, $\mathrm{t}$ was calculated using a relationship;

$$
\operatorname{Moistureratio}(M R)=\frac{M_{t}-M_{e}}{M_{i}-M_{e}}=e^{-k t}
$$

Where,

$\mathrm{M}_{\mathrm{i}}$ and $\mathrm{M}_{\mathrm{e}}$ are the initial and equilibrium dry basis moisture contents percentage

$\mathrm{M}_{\mathrm{t}}$ is dry basis moisture content at any time ' $\mathrm{t}$ '

$k$ is the drying rate constant per minute

$\mathrm{t}$ is the drying time (min).

The values of $M_{e}$ are relatively small compared to $M_{\mathrm{t}}$ and $M_{i}$, where error implied in the simplification is negligible. Drying curves was obtained for the onions. The experimental moisture ratio versus drying time data was fitted in eight thin layer drying models (Page, Logarithmic, Henderson and Pabis, Newton (Lewis), Wang and Singh, Parabolic, Midilli et al. [25] widely used to describe the drying characteristics of most food products and the best model selected [37,38] (Table 1). The acceptability of the model was determined by the coefficient of determination $\mathrm{R}^{2}$. In addition to the coefficient of determination, the goodness of fit was determined by various statistical parameters such as reduced mean square of the deviation $\chi^{2}$ and root mean square error (RMSE). For quality fit, $\mathrm{R}^{2}$ value should be higher, close to one, and $\chi^{2}$ and RSME values should be lower [34,39].

The statistical parameters were calculated by using the following relationships; 
Citation: Hussein JB, Soji MY, Abiona OO, Oke MO (2018) Drying Characteristics of Osmotically Pretreated Red Onion Slices via Hot Air Oven. J Food Process Technol 9: 733. doi: 10.4172/2157-7110.1000733

Page 3 of 8

\begin{tabular}{|c|c|c|}
\hline Model name & Model equation & References \\
\hline Wang and Singh & $M R=1+k t+c t^{2}$ & Hussein et al. [34], Wang and Singh [60] \\
\hline Prakash and Kumar & $M R=a t^{3}+b t^{2}+c t+d$ & Prakash and Kumar [61] \\
\hline Page & $M R=\exp \left(-k t^{n}\right)$ & Hussein et al. [34], Hassan-Beygi et al. [62] \\
\hline Logarithmic & $M R=a \exp (-\mathrm{kt})+\mathrm{b}$ & Tunde-Akintunde and Oke [30], Khazaei et al. [63] \\
\hline Henderson and Pabis & $M R=a \exp (-k t)$ & Tunde-Akintunde et al. [30], Tunde-Akintunde and Oke [52] \\
\hline Newton (Lewis) & $M R=\exp (-k t)$ & Hussein et al. [34], Tunde-Akintunde and Oke [52] \\
\hline Parabolic & $M R=a+k t+c t^{2}$ & Midilli et al. [25] \\
\hline
\end{tabular}

Table 1: Mathematical models fitted to red onion slices drying curves.

$$
x^{2}=\frac{\left[\sum_{i=1}^{N}\left(M R_{\text {pre }, i}-M R_{\exp , i}\right)^{2}\right]}{N-n}
$$

$$
R S M E=\sqrt{\left.\frac{1}{N} \sum_{i=1}^{N}\left(M R_{\text {pre }, i}-M R_{\text {pre }, i}\right)^{2}\right]}
$$

Determination of moisture effective diffusivities: In drying, diffusivity is used to indicate the flow of moisture out of material. In falling rate period of drying, moisture transfer within the food is mainly by molecular diffusion. Moisture diffusivity is influenced by shrinkage, case hardening during drying, moisture content and temperature of material. The falling rate period of biological materials is best described by Fick's second law of diffusion [40]. Uniform initial moisture distribution throughout the sample, negligible external resistance to movement and onion slices releasing the moisture from top as well as from bottom surface are assumed. The solution to this equation developed by Crank [40] can be applied for onion slices:

$M R=\frac{\theta}{\pi^{2}} \sum_{n=0}^{\infty} \frac{1}{(2 n+1)^{2}} \exp \left(-\frac{(2 n+1)^{2} D_{\text {eff }} \pi^{2}}{4 l^{2}} t\right)$

Where;

$\mathrm{D}_{\text {eff }}$ : Effective moisture diffusivity, $\mathrm{m}^{2} / \mathrm{s}$

T: Drying time, $s$

L: Half thickness of a thin layer sample, $\mathrm{m}$; and $\mathrm{n}$ is a positive integer

For long drying time, only the first term of equation 5 is significant [41] and then the solution becomes;

$M R=\frac{\theta}{\pi^{2}} \exp \left(-\frac{D_{\text {eff }} \pi^{2}}{4 l^{2}} t\right)$

This could be further simplified to a straight-line equation as;

$$
\operatorname{In}(M R)=\operatorname{In}\left(\frac{\theta}{\pi^{2}}\right)-\left(\frac{D_{e f f} \pi^{2}}{4 l^{2}} t\right)
$$

The effective moisture diffusivity values were determined by plotting experimental drying data in terms of $\ln (\mathrm{MR})$ versus drying time t. A plot of $\ln (\mathrm{MR})$ versus drying time gives a straight line with a slope;

$$
\text { slope }=-\frac{D_{e f f} \pi^{2}}{4 l^{2}}
$$

Knowing the onions slice thickness and the slope from the above plot, the moisture diffusivity $\left(\mathrm{D}_{e f f}\right)$ will be calculated.

Determination of activation energy: The dependence of the effective diffusivity on the different drying temperature can be predicted appropriately using the Arrhenius equation which is given by Simal, Femenia, Carcel and Rossello [42]:

$$
D_{\text {eff }}=D_{o} \exp \left(-\frac{E_{a}}{R(T+273.15)}\right)
$$

Where $\mathrm{D}_{\text {eff }}$ is the effective moisture diffusivity in $\mathrm{m}^{2} / \mathrm{s}, \mathrm{D}_{\mathrm{o}}$ is the preexponential factor of Arrhenius equation or maximum diffusion coefficient (at infinite temperature) in $\mathrm{m}^{2} / \mathrm{s}, \mathrm{Ea}$ is the activation energy in $\mathrm{kJ} / \mathrm{mol}, R$ is the universal gas constant in $\mathrm{kJ} / \mathrm{mol} \mathrm{K}$, and $\mathrm{T}$ is temperature in ${ }^{\circ} \mathrm{C}$.

Linearizing the equation gives

$$
\text { InDeff }=\left(-\frac{1}{R(T+273.15)}\right) E_{a}+\ln D_{o}
$$

The activation $\mathrm{E}_{a}$ was obtained by plotting $\mathrm{Ln} \mathrm{D}_{\text {eff }}$ against $\left(-\frac{1}{R(T+273.15)}\right)$

\section{Results and Discussion}

\section{Drying curves of red onion sliced}

The change in moisture content of red onion slices with drying time in hot air oven at different drying temperatures $\left(40^{\circ} \mathrm{C}, 50^{\circ} \mathrm{C}, 60^{\circ} \mathrm{C}\right.$, $70^{\circ} \mathrm{C}$ and $80^{\circ} \mathrm{C}$ ) was presented in Figure 1 . It was observed that as the drying temperatures increases the drying time reduced. The drying time reached the equilibrium moisture content at $660,600,390,300$ and $180 \mathrm{~min}$ for $40^{\circ} \mathrm{C}, 50^{\circ} \mathrm{C}, 60^{\circ} \mathrm{C}, 70^{\circ} \mathrm{C}$ and $80^{\circ} \mathrm{C}$, respectively. The moisture content of onion slices decreased exponentially with elapsed drying time. That is, as the air temperature increased, other drying conditions being same, the drying curves became steeper indicating higher moisture removal rates which thus resulted into substantial decrease in drying time. Similar result was reported by Madamba et al. [43], at the beginning, the moisture content reduced rapidly and then decreased slowly with increase in drying time. Drying temperature has an important effect on drying at higher temperature, due to the quick removal of moisture, the drying time was shorter. Similar observations were reported for drying of garlic slices [43], onion slices [16,44], egg plants [45] and tomato slice [46]. The osmotic solution also resulted into removal of substantial amount of moisture from the onion slices thus, decrease the drying time. It was obvious from the results that the initial osmotic dehydration shortens drying time depending on the kind of osmotic active substance used, the time of osmotic pre-concentration and final water content of the dried product [47]. Baroni and Hubinger [48] reported that the drying time of onions can be reduced to less than half by introducing an hour of osmotic dehydration in a salt solution.

\section{Effective moisture diffusivity of red dried onion slices}

It was reported that the mechanisms of mass transfer in food are 


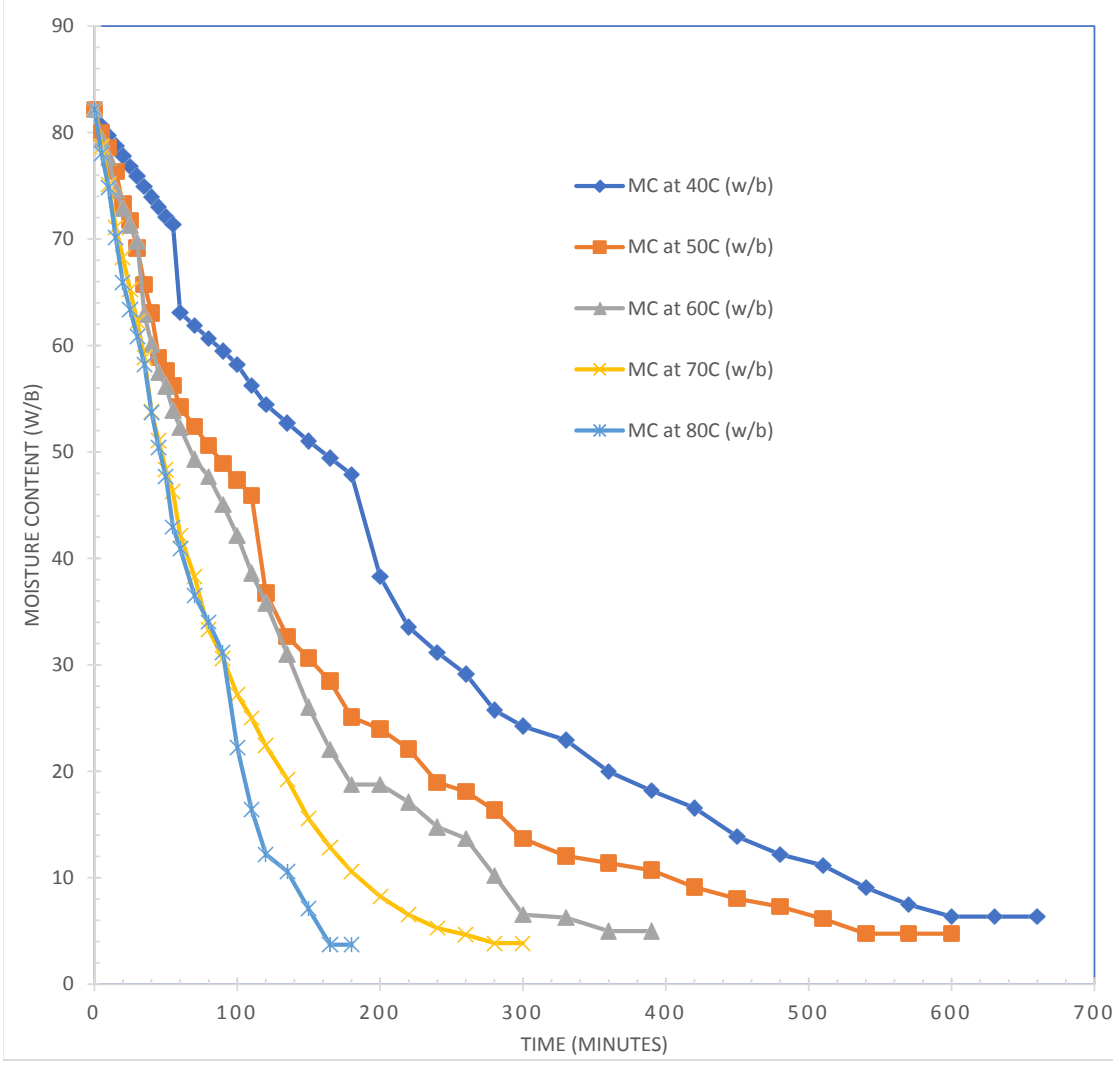

Figure 1: The drying curve of red onion slices.

complex in nature [46]. The water migrates from the inside of the product to the surface under the effect of various mechanisms which can be combined. In this study, only a falling rate drying period, which resulted in shrinkage of the dried onion slices, was observed. Thus, the main mechanism of the water transport for the onion slices is considered as diffusive type. The method of slopes as shown in eq. (7) was used to calculate the effective moisture diffusivity coefficient. Slope of graphs of $\mathrm{Ln}$ (MR) versus time for the experimental drying were determined. The effective moisture diffusivity values were found to be $1.77 \times 10^{-10} \mathrm{~m}^{2} / \mathrm{s}$ for $40^{\circ} \mathrm{C}, 1.98 \times 10^{-10} \mathrm{~m}^{2} / \mathrm{s}$ for $50^{\circ} \mathrm{C}, 3.11 \times 10^{-10}$ $\mathrm{m}^{2} / \mathrm{s}$ for $60^{\circ} \mathrm{C}, 4.26 \times 10^{-10} \mathrm{~m}^{2} / \mathrm{s}$ for $70^{\circ} \mathrm{C}$ and $7.03 \times 10^{-10} \mathrm{~m}^{2} / \mathrm{s}$ for $80^{\circ} \mathrm{C}$. This results is similar to $0.83 \times 10^{-10}$ to $1.30 \times 10^{-10} \mathrm{~m}^{2} / \mathrm{s}$ reported by Revaskar et al. [16] for osmotically pretreated onion slices in the drying air temperature range of $50^{\circ} \mathrm{C}-70^{\circ} \mathrm{C}$ but slightly faster than those of 3.65 $\times 10^{-9}$ to $9.53 \times 10^{-9} \mathrm{~m}^{2} / \mathrm{s}$ reported by Mota et al. [49] for onion slices in the drying air temperature range of $30^{\circ} \mathrm{C}-60^{\circ} \mathrm{C}$ and $3.49 \times 10^{-8}$ to 9.44 $\times 10^{-8} \mathrm{~m}^{2} / \mathrm{s}$ reported by Demiray et al. [2] onion slices in the drying air temperature range of $50^{\circ} \mathrm{C}-70^{\circ} \mathrm{C}$. However, the $\mathrm{D}_{\text {eff }}$ values obtained for red onion slices in this study lie within the general range of $10^{-12}$ to $10^{-8}$ $\mathrm{m}^{2} / \mathrm{s}$ for drying agricultural materials $[33,49]$.

The drying temperature has a significant effect on the internal mass transfer during drying since the higher the drying temperature, the shorter the time of drying. Diffusion of moisture from the internal regions to the surface occurs. This is because surface water removal is faster at higher temperature [50-52]. Revaskar et al. [16] reported that effective moisture diffusivity with osmotic pretreatment can increase due to loosening of the surface cellular structure and leaching of some soluble components of the external cell layers of onion slices during soaking in osmotic solution.

\section{Modeling on drying characteristic of red onions slices}

The summary of model parameters of the eight thin layer drying models obtained from the non-linear regression of the models are shown in Table 2. The statistical results obtained from the non-linear regression of the models which include the criteria for evaluating goodness: coefficient of determination $\left(\mathrm{R}^{2}\right)$, the reduced chi-square $\left(\chi^{2}\right)$, and root mean square error (RMSE). The selection of the best model for predicting the drying characteristics of red onions slice is based on the model having the highest $\mathrm{R}^{2}$ value and lowest $\chi^{2}$ and RMSE value [33]. The overall value of $\mathrm{R}^{2}(0.9999)$ obtained from the Midilli model is higher than those overall correlation coefficients that was found for Page (0.9980), Logarithmic (0.994), Henderson and Pabis (0.988), Newton (0.983), Wang and Singh (0.725), Parabolic (0.9000) and Prakash and Kumar models (0.969). Thus, the Midilli model best fitted to the experimental dimensionless moisture content data followed by the Page model. However, considering the model that had the lowest $\chi^{2}$ and RMSE values, Page model $\left(\chi^{2}=0.000134\right.$ and RMSE $=0.011354)$ best fitted to the dimensionless moisture content data followed by Midilli ( $\chi^{2}=0.000273$ and RMSE $\left.=0.016165\right)$, Henderson and Paris $\left(\chi^{2}=0.000829\right.$ and RMSE $\left.=0.028291\right)$, Logarithmic $\left(\chi^{2}=0.00086\right.$ and RMSE $=0.028811)$, Newton $\left(\chi^{2}=0.001124\right.$ and RMSE $\left.=0.032948\right)$, Prakash Kumar $\left(\chi^{2}=0.00304\right.$ and RMSE $\left.=0.054463\right)$, Parabolic $\left(\chi^{2}=0.009297\right.$ and RMSE $\left.=0.09524\right)$ and Wang and Singh $\left(\chi^{2}=0.025331\right.$ 
Citation: Hussein JB, Soji MY, Abiona OO, Oke MO (2018) Drying Characteristics of Osmotically Pretreated Red Onion Slices via Hot Air Oven. J Food Process Technol 9: 733. doi: 10.4172/2157-7110.1000733

Page 5 of 8

\begin{tabular}{|c|c|c|c|c|c|}
\hline Model & Constant & Temperature & $\mathbf{R}^{2}$ & $x^{2}$ & RSME \\
\hline \multirow{5}{*}{ Page } & $k=0.025 ; n=0.83$ & 40 & 0.990 & 0.000891 & 0.029113 \\
\hline & $k=0.054 ; n=0.760$ & 50 & 0.989 & 0.000754 & 0.027112 \\
\hline & $k=0.056 ; n=0.774$ & 60 & 0.992 & 0.000607 & 0.024247 \\
\hline & $\mathrm{k}=0.074 ; \mathrm{n}=0.778$ & 70 & 0.998 & 0.000134 & 0.011354 \\
\hline & $\mathrm{k}=0.079 ; n=0.774$ & 80 & 0.998 & 0.000142 & 0.011661 \\
\hline \multirow{5}{*}{ Logarithmic } & $k=0.012 ; a=0.927 ; b=0.038$ & 40 & 0.989 & 0.000932 & 0.030154 \\
\hline & $k=0.023 ; a=0.925 ; b=0.042$ & 50 & 0.988 & 0.000955 & 0.030506 \\
\hline & $k=0.026 ; a=0.917 ; b=0.043$ & 60 & 0.989 & 0.001304 & 0.035544 \\
\hline & $k=0.035 ; a=0.921 ; b=0.032$ & 70 & 0.994 & 0.00086 & 0.028811 \\
\hline & $\mathrm{k}=0.037 ; a=0.910 ; b=0.035$ & 80 & 0.990 & 0.0016675 & 0.040022 \\
\hline \multirow{5}{*}{$\begin{array}{c}\text { Henderson and } \\
\text { Pabis }\end{array}$} & $\mathrm{k}=0.011 ; a=0.945$ & 40 & 0.984 & 0.001375 & 0.036624 \\
\hline & $\mathrm{k}=0.020 ; a=0.938$ & 50 & 0.976 & 0.001646 & 0.040045 \\
\hline & $\mathrm{k}=0.022 ; \mathrm{a}=0.932$ & 60 & 0.980 & 0.001424 & 0.037147 \\
\hline & $\mathrm{k}=0.031 ; a=0.933$ & 70 & 0.988 & 0.000829 & 0.028291 \\
\hline & $\mathrm{k}=0.033 ; a=0.923$ & 80 & 0.986 & 0.001006 & 0.031021 \\
\hline \multirow{5}{*}{ Newton (Lewis) } & $\mathrm{k}=0.012$ & 40 & 0.981 & 0.001672 & 0.040383 \\
\hline & $\mathrm{k}=0.022$ & 50 & 0.973 & 0.001883 & 0.04283 \\
\hline & $k=0.024$ & 60 & 0.975 & 0.001761 & 0.041306 \\
\hline & $k=0.034$ & 70 & 0.983 & 0.001124 & 0.032948 \\
\hline & $k=0.036$ & 80 & 0.979 & 0.001489 & 0.037745 \\
\hline \multirow{5}{*}{ Wang and Singh } & $\mathrm{k}=-0.006 ; c=6.706 \times 10^{-6}$ & 40 & 0.714 & 0.025331 & 0.157205 \\
\hline & $\mathrm{k}=-0.007 ; \mathrm{c}=9.558 \times 10^{-6}$ & 50 & 0.190 & 0.074544 & 0.269504 \\
\hline & $k=-0.010 ; c=2.082 \times 10^{-5}$ & 60 & 0.477 & 1.338799 & 1.138842 \\
\hline & $k=-0.013 ; c=3.560 \times 10^{-5}$ & 70 & 0.401 & 8.106664 & 2.7977 \\
\hline & $\mathrm{k}=-0.019 ; c=7.979 \times 10^{-5}$ & 80 & 0.725 & 102.368 & 9.895311 \\
\hline \multirow{5}{*}{ Parabolic } & $k=-0.004 ; c=4.271 \times 10^{-6} ; a=0.755$ & 40 & 0.895 & 0.009297 & 0.09524 \\
\hline & $k=-0.004 ; c=4.831 \times 10^{-6} ; a=0.608$ & 50 & 0.774 & 0.019587 & 0.138148 \\
\hline & $k=-0.006 ; c=1.155 \times 10^{-5} ; a=0.673$ & 60 & 0.835 & 0.359334 & 0.590004 \\
\hline & $k=-0.007 ; c=1.929 \times 10^{-5} ; a=0.645$ & 70 & 0.817 & 2.173204 & 1.448539 \\
\hline & $k=-0.012 ; c=4.974 \times 10^{-5} ; a=0.745$ & 80 & 0.900 & 37.21861 & 5.966608 \\
\hline \multirow{5}{*}{ Midilli et al. } & $k=0.025 ; b=3.237 \times 10^{-5} ; a=1.015 ; n=0.834$ & 40 & 0.991 & 0.000788 & 0.027734 \\
\hline & $k=0.058 ; b=4.355 \times 10^{-5} ; a=1.036 ; n=0.755$ & 50 & 0.992 & 0.000627 & 0.024713 \\
\hline & $k=0.056 ; b=5.796 \times 10^{-5} ; a=1.017 ; n=0.784$ & 60 & 0.993 & 0.00082 & 0.028182 \\
\hline & $k=0.073 ; b=5.080 \times 10^{-5} ; a=1.010 ; n=0.786$ & 70 & 0.999 & 0.000376 & 0.019055 \\
\hline & $k=0.083 ; b=-3.158 \times 10^{-5} ; a=1.006 ; n=0.761$ & 80 & 0.998 & 0.000273 & 0.016165 \\
\hline \multirow{5}{*}{ Prakash and Kumar } & $a=-1.385 \times 10^{-8} ; b=1.717 \times 10^{-5} ; c=-0.007 ; d=0.869$ & 40 & 0.966 & 0.00304 & 0.054463 \\
\hline & $a=-2.169 \times 10^{-8} ; b=2.321 \times 10^{-5} ; c=-0.008 ; d=0.743$ & 50 & 0.897 & 0.011196 & 0.104446 \\
\hline & $a=-7.142 \times 10^{-8} ; b=5.118 \times 10^{-5} ; c=-0.011 ; d=0.811$ & 60 & 0.939 & 1.882918 & 1.350584 \\
\hline & $a=-1.605 \times 10^{-7} ; b=8.830 \times 10^{-5} ; c=-0.015 ; d=0.794$ & 70 & 0.936 & 27.3236 & 5.136283 \\
\hline & $a=-5.542 \times 10^{-7} ; b=0.000 ; c=-0.022 ; d=0.868$ & 80 & 0.969 & 1101.916 & 32.46547 \\
\hline
\end{tabular}

Table 2: Estimated parameters and comparison criteria of moisture ratio of red onion slices.

and RMSE $=0.157205$ ) models. Thus, from the above results, it was observed that the Midilli model satisfactorily describes the drying characteristic of osmotically pretreated red onion slices dried in a hot air oven.

The experimental and the predicted data values using Midilli model for moisture ratios of osmotically pretreated red onion slices dried in a hot air oven is shown in Figure 2. The established model provided a very good conformity between the experimental data and the predicted moisture ratios of the osmotically pretreated red onion slices. It was observed that the predicted data are banded around the ideal trend line indicating the suitability of the model in predicting the drying behavior of osmotically pretreated red onion slices dried in a hot air oven.

\section{Activation energy}

The activation energy was obtained from a graph of Ln D versus the reciprocal of the absolute temperature $1 /$ Tabs (Figure 3 ) and it was calculated using eq. 10. The activation energy (Ea) for diffusion of moisture for red onion was calculated and found to be $29.67 \mathrm{KJ} / \mathrm{mol}$. Similar results of $26.83 \mathrm{KJ} / \mathrm{mol}$ by Babu et al. [53] and $26.40 \mathrm{KJ} / \mathrm{mol}$ by Mota et al. [49] were reported for the diffusion of water from onion. The activation energy is determined by the forms in which water exists in foods, namely surface absorption and chemical absorption. The activation energy is a measure of the temperature sensitivity of $\mathrm{D}_{\text {eft }}$ and it is the energy needed to initiate the moisture diffusion within the seed [54]. This activation energy is in reasonable agreement with the data presented by several other authors, for example $27.61 \mathrm{~kJ} /$ mol for corn [55], $28.40 \mathrm{~kJ} / \mathrm{mol}$ for green peas [56], $28.36 \mathrm{~kJ} / \mathrm{mol}$ for carrot [57], $30.79 \mathrm{~kJ} / \mathrm{mol}$ for pistachio nut [57,58] and $28.15 \mathrm{~kJ} / \mathrm{mol}$ for tiger nut seed [52]. The differences in activation energy value vary from product to product as attributed due to product characteristics and process parameters as noted by Villota and Hawkes [59]. However, the activation energy obtained for each variety is within the general 
Citation: Hussein JB, Soji MY, Abiona OO, Oke MO (2018) Drying Characteristics of Osmotically Pretreated Red Onion Slices via Hot Air Oven. J Food Process Technol 9: 733. doi: 10.4172/2157-7110.1000733

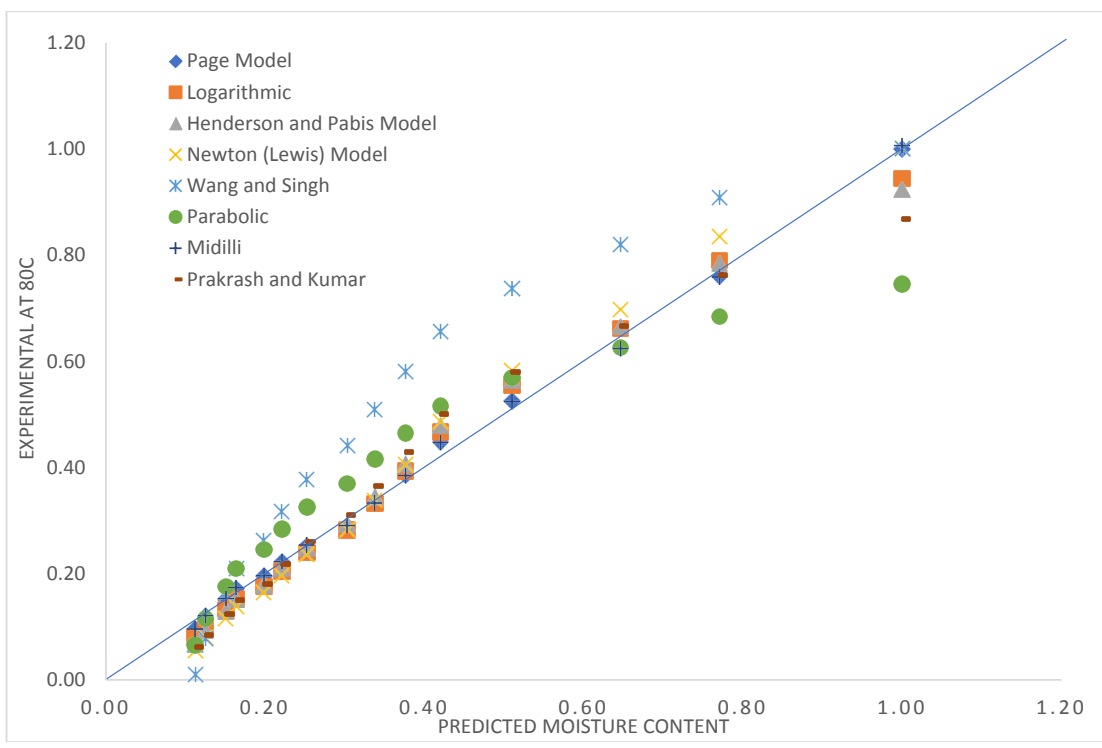

Figure 2: Experimental and predicted drying curves for osmotically pretreated red onion slices at $80^{\circ} \mathrm{C}$.

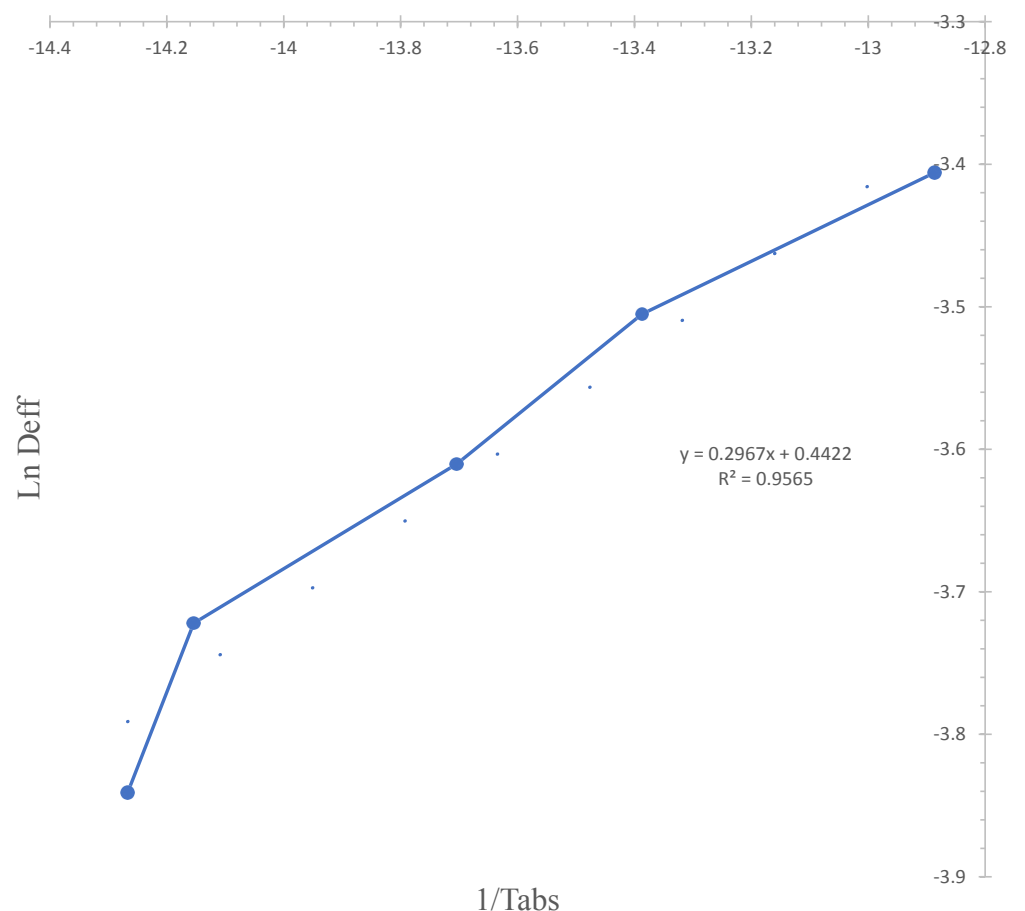

Figure 3: Activation energy of osmotically pretreated red onion slices.

range of $12.7-110 \mathrm{~kJ} / \mathrm{mol}$ [59] for most agricultural and food materials as presented by several other reports [60-64].

\section{Conclusion}

The drying characteristic of osmotically pretreated red onion slices via hot air oven at $40^{\circ} \mathrm{C}$ to $80^{\circ} \mathrm{C}$ drying temperature and $1.5 \mathrm{~m} / \mathrm{s}$ air velocity was investigated in this study. The initial osmotic dehydration resulted into removal of substantial amount of moisture from the onion slices thereby shorten the drying time. The entire drying process occurred in falling rate period and constant rate period was not observed. Eight drying models (Page, Logarithmic, Henderson and Pabis, Newton (Lewis), Wang and Singh, Parabolic, Midilli, Prakash and Kumar) were used to optimize the goodness of fit to the experimental data. The Midilli model was found to best fit the experimental data compared to other models. The effective moisture diffusivity values were found to be $1.76838 \times 10^{-10} \mathrm{~m}^{2} / \mathrm{s}$ for $40^{\circ} \mathrm{C}, 1.98 \times 10^{-10} \mathrm{~m}^{2} / \mathrm{s}$ for $50^{\circ} \mathrm{C}, 3.11 \times 10^{-10}$ $\mathrm{m}^{2} / \mathrm{s}$ for $60^{\circ} \mathrm{C}, 4.26 \times 10^{-10} \mathrm{~m}^{2} / \mathrm{s}$ for $70^{\circ} \mathrm{C}$ and $7.03 \times 10^{-10} \mathrm{~m}^{2} / \mathrm{s}$ for $80^{\circ} \mathrm{C}$ respectively. The activation energy (Ea) was found to be $29.67 \mathrm{KJ} / \mathrm{mol}$. 
Citation: Hussein JB, Soji MY, Abiona OO, Oke MO (2018) Drying Characteristics of Osmotically Pretreated Red Onion Slices via Hot Air Oven. J Food Process Technol 9: 733. doi: 10.4172/2157-7110.1000733

\section{References}

1. FAOSTAT (2017) Global okra production in 2016. Food and Agriculture Organization of the United Nations.

2. Demiray E, Seker A, Tulek Y (2016) Drying kinetics of onion (Allium cepa L) slices with convective and microwave drying. Heat Mass Transfer 53: 18171827.

3. Mogren LM, Olsson ME, Gertsson UE (2007) Quercetin content in stored onions (Allium cepa L.): Effects of storage conditions, cultivar, lifting time and nitrogen fertiliser level. J Sci Food Agri 87: 1595-1602.

4. Tarwadi K, Agte V (2005) Antioxidant and micronutrient quality of fruit and roo vegetables from the Indian subcontinent and their comparative performance with green leafy vegetables and fruits. J Sci Food Agri 85: 1469-1476.

5. Randle WM (1997) Onion flavour chemistry and factors influencing flavour intensity: Flavor chemistry and antioxidant properties. ACS Symposium, Washington DC, USA. pp: 41-52.

6. Patil MM, Kalse SB, Jain SK (2012) OSMO-convective drying of onion slices. Res J Recent Sci 1: 51-9.

7. Ayodele VI (1996) Onion Allium cepa L. var. aggregatun production in Ibadan South West Nigeria: Prospect and limitation. $11^{\text {th }}$ Annual conference of the horticultural society of Nigeria, Ogun State University, Agolwoye.

8. Block E (1994) Food Phytochemicals for cancer prevention. American Chemical Symposium Series.

9. Hussein JB, Usman MA, Filli KB (2016c) Effect of hybrid solar drying method on the functional and sensory properties of tomato. America J Food Sci Technol 4: 141-148.

10. Kaymak-Ertekin F, Gedik A (2005) Kinetic modelling of quality deterioration in onions during drying and storage. J Food Eng 68: 443-453.

11. Jayeeta M, Shrivastava SL, Rao PS (2011) Process optimisation of vacuum drying of onion slices. Czech J Food Sci 29: 586-594.

12. Azoubel PM, El-Aouar ÂA, Tonon RV, Kurozawa LE, Antonio GC, et al. (2009) Effect of osmotic dehydration on the drying kinetics and quality of cashew apple. Int J Food Sci Technol 44: 980-986.

13. Fernandes FA, Gallão MI, Rodrigues S (2008) Effect of osmotic dehydration and ultrasound pre-treatment on cell structure: melon dehydration. LWT-Food Sci Technol 41: 604-610.

14. Lombard GE, Oliveira JC, Fito P, Andrés A (2008) Osmotic dehydration of pineapple as a pre-treatment for further drying. J Food Eng 85: 277-284.

15. Hathan BS, Malhotra T (2012) Drying kinetics of osmotically pretreated carro shreds to be used for preparation of sweet meat. Agri Eng Int: CIGR J 14 $125-135$

16. Revaskar VA, Pisalkar PS, Pathare PB, Sharma GP (2014) Dehydration kinetics of onion slices in osmotic and air convective drying process. Res Agri Engg 60: 92-99.

17. Sereno AM, Moreira R, Martinez E (2001) Mass transfer coefficients during osmotic dehydration of apple in single and combined aqueous solutions of sugar and salt. J Food Eng 47: 43-49.

18. McMinn WA, Magee TR (1999) Studies on the effect of surfactant, blanching and osmotic pretreatments on the convective drying of potatoes. J Food Process Eng 22: 419-433.

19. Ade-Omowaye BI, Talens P, Angersbach A, Knorr D (2003) Kinetics of osmotic dehydration of red bell peppers as influenced by pulsed electric field pretreatment. Food Res Int 36: 475-483.

20. Babalis SJ, Belessiotis VG (2004) Influence of the drying conditions on the drying constants and moisture diffusivity during the thin-layer drying of figs. $J$ Food Eng 65: 449-458.

21. Mirzaee E, Rafiee S, Keyhani A (2010) Evaluation and selection of thin-layer models for drying kinetics of apricot (cv. NASIRY). Agri Eng Int: CIGR J 12: 111-116.

22. Doymaz I (2007) Air-drying characteristics of tomatoes. J Food Eng 78: 1291-1297.

23. Purkayastha MD, Nath A, Deka BC, Mahanta CL (2003) Thin layer drying of tomato slices. J Food Sci Technol 50: 642-653.

24. Doymaz I (2005) Drying behaviour of green beans. J Food Eng 69: 161-165.
25. Midilli A, Kucuk H (2003) Mathematical modeling of thin layer drying of pistachio by using solar energy. Energy Convers Manage 44: 1111-1122.

26. Akpinar EK, Bicer Y, Yildiz C (2003) Thin layer drying of red pepper. J Food Eng 59: 99-104.

27. Akpinar EK (2010) Drying of mint leaves in a solar dryer and under open sun Modelling, performance analyses. Energy Conv Manag 51: 2407-2418.

28. Arabhosseini A, Huisman W, Van Boxtel A, Müller J (2009) Modeling of thin layer drying of tarragon (Artemisia dracunculus L.). Ind Crop Prod 29: 53-59.

29. Aghbashlo M, Kianmehr MH, Arabhosseini A (2009) Modeling of thin-layer drying of potato slices in length of continuous band dryer. Energ Convers Manage 50: 1348-1355.

30. Tunde-Akintunde TY (2011) Mathematical modeling of sun and solar drying of chilli pepper. Renew Energy 36: 2139-2145.

31. Berruti FM, Klaas M, Briens C, Berruti F (2009) Model for convective drying of carrots for pyrolysis. J Food Eng 92: 196-201.

32. Mohamed LA, Kouhila M, Jamali A, Lahsasni S, Kechaou N, et al. (2005) Single layer solar drying behaviour of Citrus aurantium leaves under forced convection. Energy Convers Manage 46: 1473-1483.

33. Bagheri H, Arabhosseini A, Kianmehr MH, Chegini GR (2013) Mathematical modeling of thin layer solar drying of tomato slices. Agri Eng Int: CIGR J 15: 146-153.

34. Hussein JB, Filli KB, Oke MO (2016) Thin layer modelling of hybrid, solar and open sun drying of tomato slices. Res J Food Sci Nutri 1: 15-27.

35. Kulanthaisami S, Rajkumar $P$, Venkatachalam $P$, Subramanian $P$, Raghavan GS, et al. (2010) Drying kinetics of tomato slices in solar cabinet dryer compared with open sun drying. Madras Agri J 97: 287-295.

36. AOAC (2010) Official Methods of Analysis. Association of Official Analytical Chemists. Washington DC, USA.

37. Akpinar EK (2006) Mathematical modelling of thin layer drying process unde open sun of some aromatic plants. J Food Eng 77: 864-870.

38. Perumal R (2007) Comparative performance of solar cabinet, vacuum assisted solar and open sun drying methods. McGill University, Canada.

39. Erenturk S, Gulaboglu M, Gultekin S (2004) The thin-layer drying characteristics of rosehip. Biosystem Eng 89: 159-166

40. Crank J (1975) Diffusion in a cylinder: The mathematics of diffusion pp: 69-88.

41. Tutuncu MA, Labuza TP (1996) Effect of geometry on the effective moisture transfer diffusion coefficient. J Food Eng 30: 433-447.

42. Simal S, Femenia A, Cárcel JA, Rosselló C (2005) Mathematical modelling of the drying curves of kiwi fruits: influence of the ripening stage. J Sci Food Agri 85: 425-432

43. Madamba PS, Driscoll RH, Buckle KA (1996) The thin-layer drying characteristics of garlic slices. J Food Eng 29: 75-97.

44. Sarsavadia PN, Sawhney RL, Pangavhane DR, Singh SP (1990) Drying behaviour of brined onion slices. J Food Eng 40: 219-226.

45. Akpinar EK, Bicer Y (2005) Modelling of the drying of eggplants in thin layers. Int J Food Sci Technol 40: 273-281.

46. Hussein JB, Sanusi MS, Filli KB (2016) Evaluation of drying methods on the content of some bio-actives (lycopene,-carotene and ascorbic acid) of tomato slices. Africa J Food Sci 10: 359-367.

47. Abou El-Hana NH (2008) Drying kinetics of osmotically-treated tomatoes. Misr J Agri Eng 25: 957-979.

48. Baroni AF, Hubinger MD (1998) Drying of onion: Effects of pretreatment on moisture transport. Dry Technol 16: 2083-2094.

49. Mota CL, Luciano C, Dias A, Barroca MJ, Guiné RP (2010) Convective drying of onion: Kinetics and nutritional evaluation. Food Bioproduct Process 88: 115-223.

50. Doymaz I (2010) Effect of citric acid and blanching pre-treatments on drying and rehydration of Amasya red apples. Food Bioproduct Process 88: 124-132.

51. Falade KO, Abbo ES (2007) Air-drying and rehydration characteristics of date palm (Phoenix dactylifera L.) fruits. J Food Eng 79: 724-730.

52. Tunde-Akintunde TY, Oke MO (2012) Thin-layer drying characteristics of tiger nut (Cyperus esculentus) seeds. J Food Process Preserv 36: 457-464. 
Citation: Hussein JB, Soji MY, Abiona OO, Oke MO (2018) Drying Characteristics of Osmotically Pretreated Red Onion Slices via Hot Air Oven. J Food Process Technol 9: 733. doi: 10.4172/2157-7110.1000733

53. Babu AS, Sarker M, Islam MN (1997) Kinetics of mechanical, solar and sun drying of onion. Bangladesh J Agri Eng 8: 28-49.

54. Workneh TS, Oke MO (2013) Thin layer modelling of microwave-convective drying of tomato slices. Int J Food Eng 9: 75-90.

55. Tolaba M, Suarez C (1988) Simulation of the thin-layer drying of corn by means of the diffusional model. LWT-Food Sci Technol 21: 83-86.

56. Kashaninejad M, Mortazavi A, Safekordi A, Tabil LG (2007) Thin-layer drying characteristics and modeling of pistachio nuts. J Food Eng 78: 98-108.

57. Doymaz I (2004) Convective air drying characteristics of thin layer carrots. $J$ Food Eng 61: 359-364.

58. Simal S, Mulet A, Tarrazo J, Rosselló C (1996) Drying models for green peas. Food Chem 55: 121-128.
59. Villota, Hawkes (1992) Kinetics in food system. In: Heldmen DR (ed.) Handbook of Food Engineering. Bethestha Publishers, UK pp: 57-85.

60. Wang GY, Singh RP (1978) Single layer drying equation for rough rice. PaperAmerican Society of Agricultural Engineers.

61. Prakash O, Kumar A (2011) Environomical analysis and mathematical modelling for tomato flakes drying in a modified greenhouse dryer under active mode. Int J Food Eng 10: 669-681.

62. Hassan-Beygi SR, Aghbashlo M, Kianmehr MH, Massah J (2009) Drying characteristics of walnut (Juglans regia L.) during convection drying. Inter Agrophysics 23: 129-135.

63. Khazaei J, Chegini GR, Bakhshiani M ( 2008) A novel alternative method for modeling the effects of air temperature and slice thicknessoon quality and drying kinetics of tomato slices: Superposition Technique. Drying Technol 26 : 759-775.

64. Shittu TA, Raji AO (2011) Thin layer drying of African Breadfruit (Treculia africana) seeds: Modeling and rehydration capacity. Food Bioprocess Technol 4: 224-231. 